\title{
Multiple-collision zones in the Sanjiang Region, SW China.
} Sotaro Baba *, Masaaki Owada **, Zilong hi **, Nobuhiko Nakano * and Yasuhito Osanai ****

Faculty of Education, University of the Ryukyus, Okinawa 903-0213, Japan

Faculty of Science, Yamaguchi University, Yamaguch 753-8512, Japan

Faculty of Science, Zhejiang University, Hangzhou 310027 , P.R. China

Japan

Received August 26, 2006 Accepted May 30, 2007

Corresponding author; Y.Osanai, osanai@scs.kyushu-u.ac.jp

The region that extends over the borders of China, Myanmar, Laos and Vietnam, corresponds to an eastern side of the Eurasia-India continental collision zones. There are several geological units, namely, Andaman Arc, West Burma, Shan-Thai, Indochina, South China, and Lhasa Blocks, and they have considered to be assembled due to the multiple-collision events in Asia. However, the detailed process and timing have not been identified yet. Recently, along these sutures, garnet-orthopyroxene-bearing granulite and phengite-eclogite in central to northern Vietnam (Nakano et al., 2006), and high-pressure jadeitites in northern Myanmar (United Nations, 1996) have been recognized (Fig. 1). The geological information preserved in the rocks along collisional sutures would give key issue understanding a multiple collision process.

We have carried out geological survey in the Sanjiang Region, southwestern China, where four continental blocks had been collided in a narrow zone. These boundaries are now recognized as a riverhead of three world famous rivers; the Yangtze, Mekong, and Salween Rivers (Fig. 2). The geology and tectonics of these areas have not been studied well, and termed as an "undifferentiated metamorphic rocks” (Leloup et al., 1995). The main investigated area located along Nujiang (Salween) River, and corresponds to suture between West Burma and Shan-Thai Blocks (Figs. 1, 3). Our study reveals that the suture is composed chiefly of highly deformed granitic mylonite with greenschist to upper amphibolite-facies metamorphic rocks. Only lowpressure metamorphic mineral assemblages (Fig. 4) could be confirmed though the existence of high-pressure assemblage was expected. The fact may imply that temporal difference in evolution of individual suture. Further investigation including Myanmar and Laos would contribute to understanding a detailed collisional process and evolutional history in Southeast Asia. This program is a part of the "Collision tectonics in Far-eastern Eurasia" project supported by the Grant-in-Aid for Scientific Research from the Japan Society for the Promotion of Science to Y. Osanai (No. 17253005).

\section{References}

Leloup, P.H., Lacassin, R., Tapponnier, P., Schärer, U., Dalai, A., Xiaochan, L., Liangshang, Z., Shaocheng, J, and Trinh, P.T., 1995, The Ailao Shan-Red River shear zone (Yunnan, China), Tertiary transform boundary of Indochina. Tectonophysics, 251, 3-84.

Nakano, N., Osanai, Y., Minh, N.T., Miyamoto, T., Owada, M. and Nam, T.R., 2006, Discovery of eclogites and related high-pressure rocks from the Song Ma suture zone in North Vietnam. Jour. Geol. (Vietnam), Ser. A, no. 296, 16-27.

United Nations, 1996, Atlas of mineral resources of the ESCAP region, 12, Viet Nam, United Nations Publication, Bangkok. 198p.

Fig. 2. $(\rightarrow)$ Regional map of the Sanjiang region. Sample localities and figure positions are also shown. Geological survey has been carried out about $250 \mathrm{~km}$ mainly along the Nujiang (Salween) River.

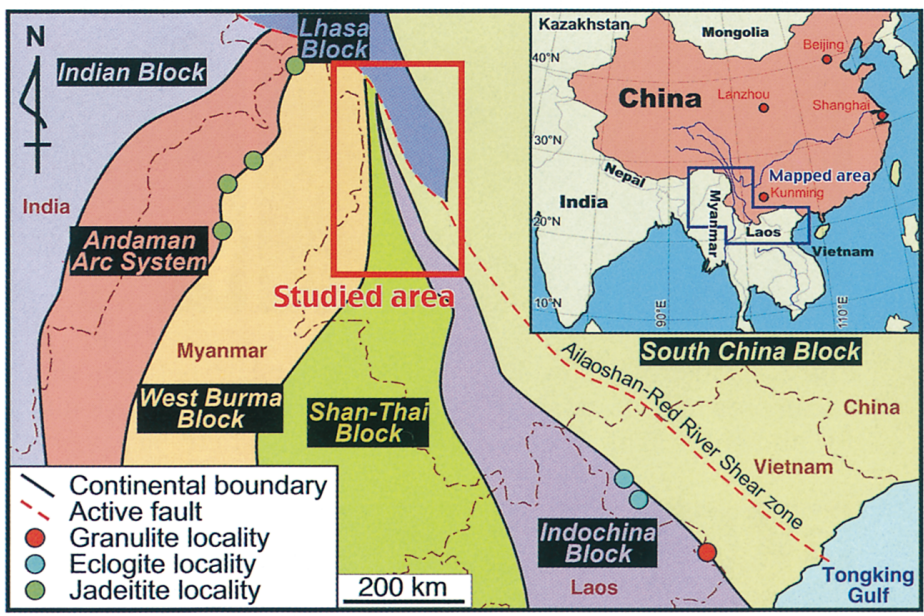

Fig. 1. Simplified distribution map showing tectonic blocks/terranes in Southeast Asia. Localities of Grt-Opx bearing granulite and phengiteeclogite (Nakano et al., 2006), and jadeitite (United Nations, 1996) are also shown.

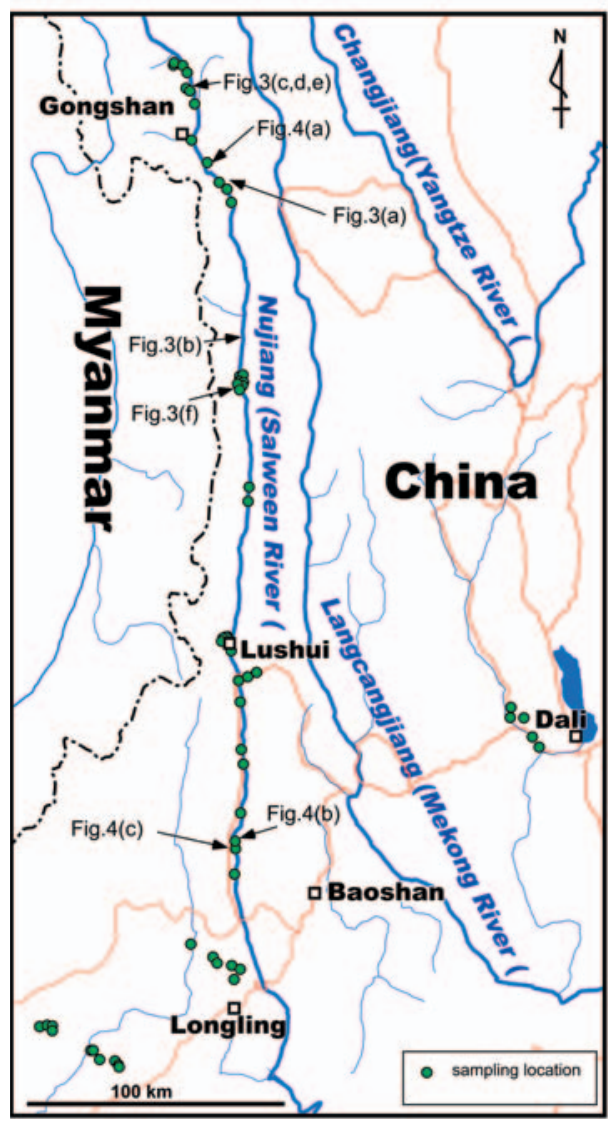



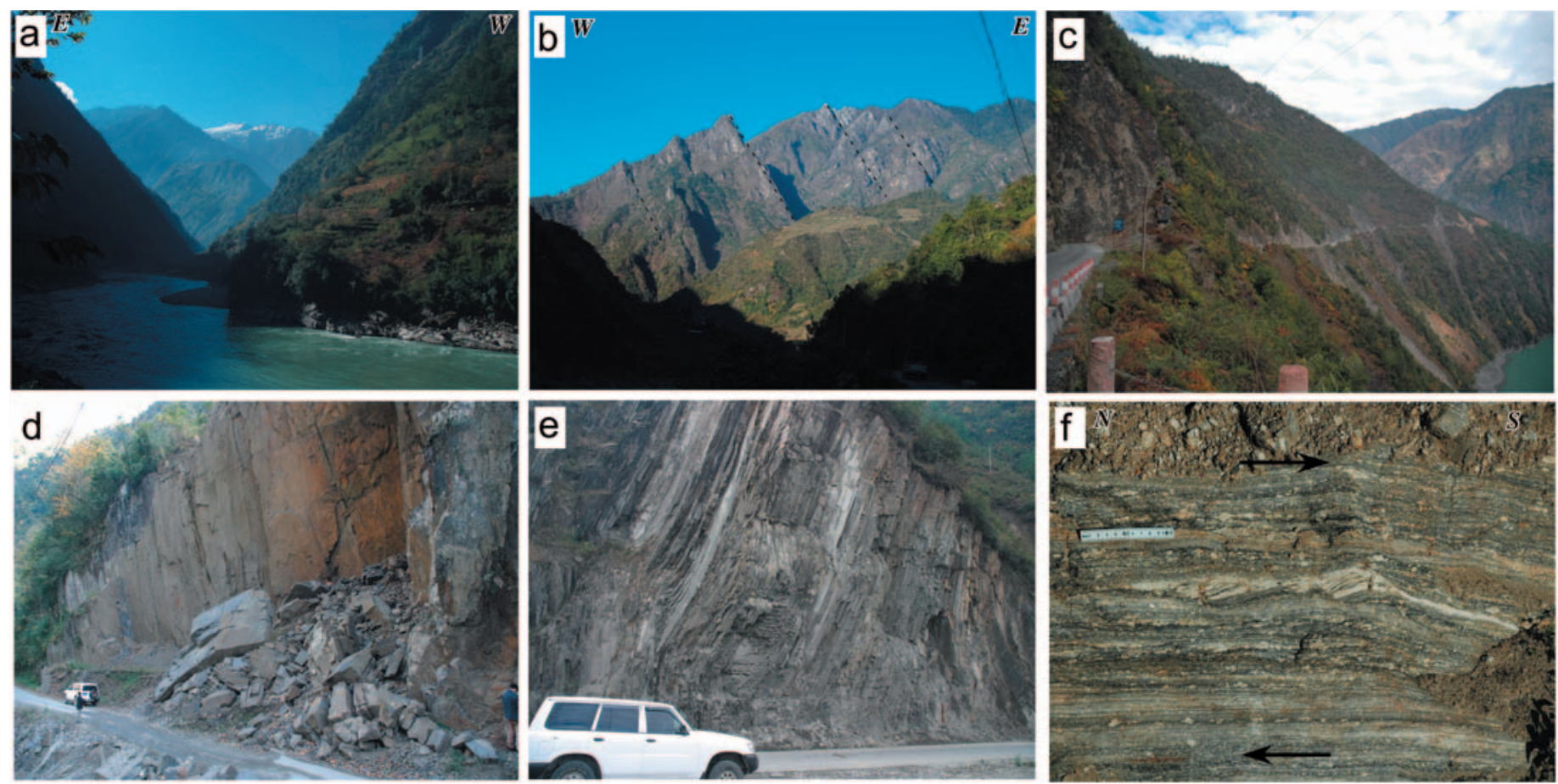

Fig. 3. Landscape showing (a) terrane boundary between the West Burma and Shan-Thai Blocks along the Nujiang (Salween) River, (b) lineaments in mountain slope trending parallel to the mylonite plane, and (c) northernmost region in investigated area. Roadside collapse (d) and outcrop of greenschist (e). (f) Sillimanite-bearing mylonitic rock showing a top to the south movement.

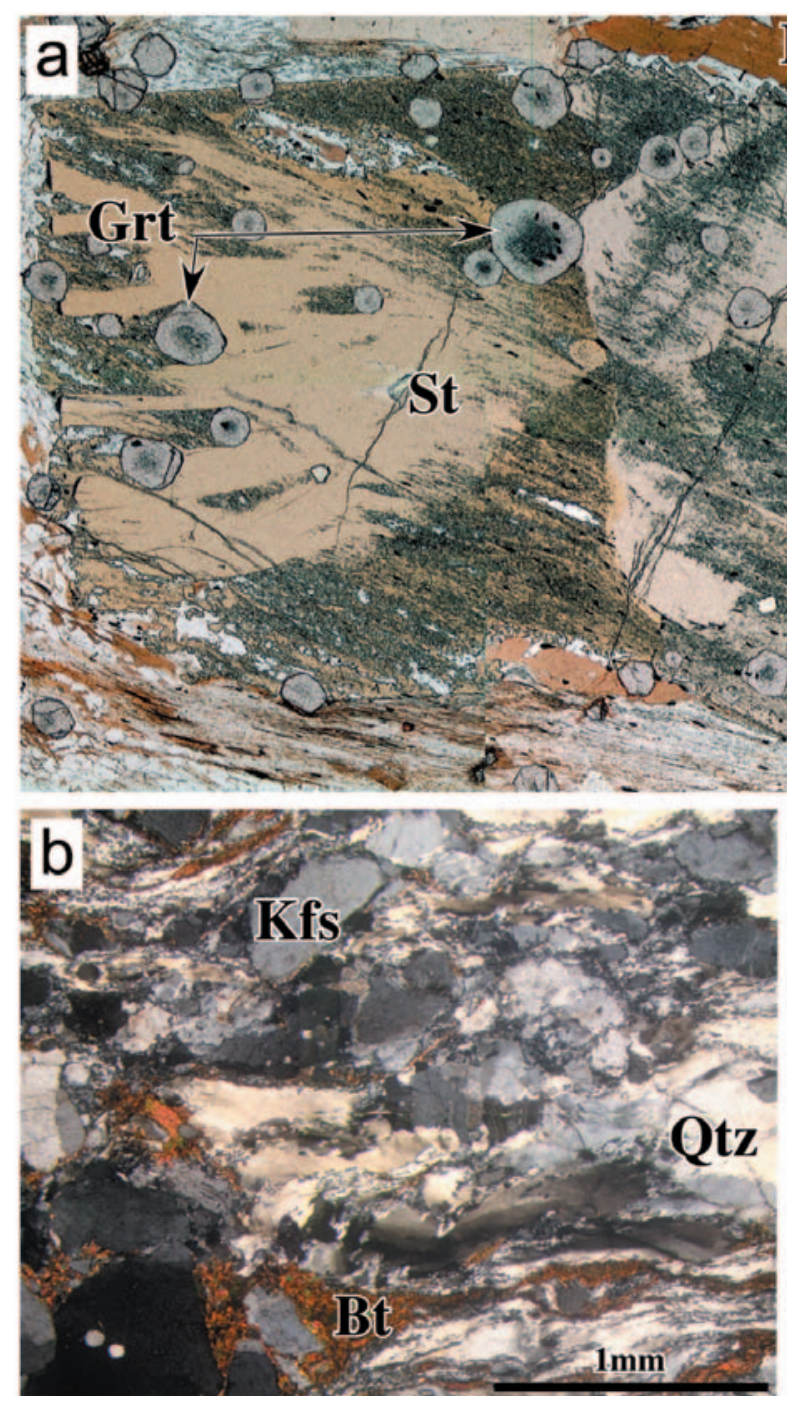

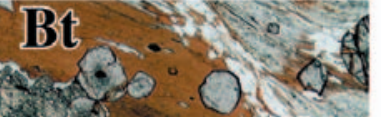
सरㄴ?
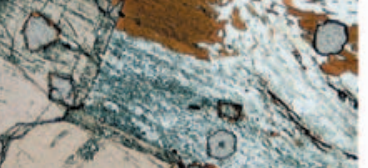
(a) s.
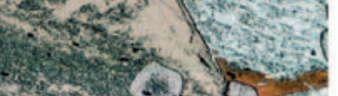

(6). $0=$
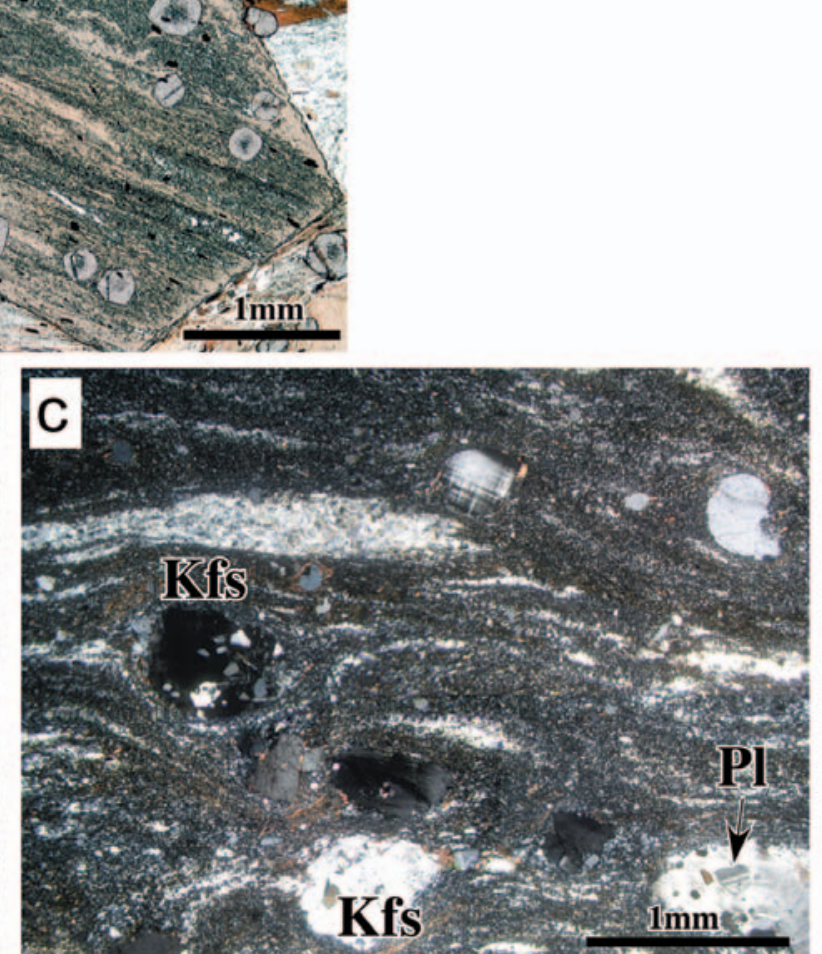

Fig. 4. Photomicrographs of pelitic gneiss and mylonites. (a) Idiomorphic staurolite (St) porphyroblast enclosing tiny sector-zoned garnet(Grt) and pre-existing foliation. (b) Granitic mylonite. A foliation formed by elongate grains of recrystallized quartz (Qtz) and biotite (Bt). (c) Ultramylonite including rounded porphyroclasts of $\mathrm{K}$ feldspar (Kfs) and plagioclase (Pl). 